\title{
PEMETAAN KUALITAS MADRASAH ALIYAH DI KABUPATEN KOLAKA
}

\section{QUALITY MAPPING OF MADRASAH ALIYAH IN KOLAKA REGENCY}

\author{
Abdul Rahman Arsyad \\ Balai Penelitian dan Pengembangan Agama Makassar \\ Jl. A. P. Petta Rani No. 72 Makassar \\ Email: arsyadrahman056@gmail.com
}

Naskah diterima tanggal 7 september 2018, Naskah direvisi tanggal 10 Oktober 2018, Naskah disetujui tanggal 5 November 2018

\begin{abstract}
Abstrak
Penelitian ini menelusuri tingkat capaian standar nasional pendidikan pada madrasah aliyah di Kabupaten Kolaka, dengan melihat delapan komponen SNP. Jenis Penelitian survey dengan menggunakan metode kuantitatif,adapuntehnik pengumpulan data, yaitu: angket, wawancara, observasi dan dokumentasi. Tingkat capaian kualitas madrasah aliyah sangat bervariatif dalam pemenuhan kualitas terhadap bebererapa aspek, diantaranya: Aspek cirri khas terutama pada, pengembangan mata pelajaran agama dan pengembangan ekstrakurikuler keagamaan belum berjalan secara signifikan, karena masih adanya keterbatasan yang dimiliki, yaitu: fasilitas pembelajaran, waktu dan sumber daya manusia pengelola madrasah. Sedangkan untuk pengembangan SDM guru dan staf, perekrutan dan penempatan perlu selektif dalam pemenuhan pembelajaran pada satuan pendidikan (madrasah), begitupun halnya pada pemenuhan sarana dan prasarana, terutama pada pemenuhan ruang, fasilitas dan media pembelajaran yang masih memerlukan perhatian secara serius dalam menunjang kualitas pembelajaran di madrasah. Manajemen madrasah, sepenuhnya merujuk pada kebijakan yayasan. Sehingga inovasi dan kreatifitas pengelola kurang menguat dalam mengembangkan madrasah, terutama membangun kerjasama pada semua elemen dalam pemenuhan operasional pembelajaran. Sehingga capaian tingkat kualitas madrasah dengan melihat pada delapan standar kualitas terkategori Tinggi 70,2\%.
\end{abstract}

Kata Kunci: Kualitas Madrasah Aliyah

\begin{abstract}
This study traces the level of achievement of national education standards at madrasah aliyah in Kolaka District, by looking at eight SNP components. Types of survey research using quantitative methods, as for data collection techniques, namely: questionnaires, interviews, observation and documentation. The level of achievement of the quality of the aliyah madrasah is very varied in fulfilling the quality of several aspects, including: Typical aspects, especially in the development of religious subjects and extracurricular religious development has not run significantly, because there are still limitations, namely: learning facilities, time and resources human power manager of the madrasah. Whereas the development of teacher and staff human resources, recruitment and placement needs to be selective in fulfilling learning in education units (madrasah), as well as fulfilment of facilities and infrastructure, especially in fulfilling space, facilities and learning media that still require serious attention in supporting the quality of learning in the madrasah. Management of madrasah, fully refers to the policy of the foundation. So that the innovation and creativity of managers are less strong in developing the madrasah, especially build cooperation on all elements in the fulfilment of operational learning. So that the achievement of the quality level of the madrasah by looking at eight categorized quality standards is High $70.2 \%$.
\end{abstract}

Keywords: Quality of Madrasah Aliyah

\section{PENDAHULUAN}

$\mathrm{P}$ emahaman dan pengetahuan masyarakat dulu tentang lembaga pendidikan madrasah sangat bervariatif. Terkadang madrasah dijadikan sebagai pilihan kedua setelah sekolah umum, begitupun halnya dengan prestasi dan keunggulan yang selalu dijadikan sebagai barometer untuk menyekolahkan anak. Pada dasarnya masyarakat 
belum memahami kalau madrasah sekarang telah mengalami pergeseran atau perubahan terutama pada aspek proses pembelajaran, mutu sarana dan prasarana, maupun pada kompetensi atau kualitas lulusan.

Penetapan Kementerian agama terhadap sasarat strategi, yaitu sebagai berikut: Pertama; Sasaran peningkatan kualitas penyelenggaraan pendidikan pada semua jenjang pendidikan dalam meningkatkan kualitas pelayanan pendidikan, diantaranya: a) Akreditasi Madrasah; b) Prodi PTK; c) Standar Nasional Pendidikan (SNP) Madrasah. Kedua; sasaran terkait peningkatan kualitas guru dan staf yang memiliki kompoten, profesional, dan bersertifikat.

Balai penelitian Dan Pengembangan Agama Makassar telah melakukan penelitian Kualitas Madrasah sejak 2013 - 2016, yang dilaksanakan di berbagai propinsi (Gorontalo, Sulbar, Kaltim, dan Sulsel), dimana memiliki tingkat kualitas yang bervariatif, walaupun sebahagian besar telah terakreditasi. Namun, dari aspek Sarpras memiliki tingkat kualitas yang rendah.

Penelitian pemetaan kualitas madrasah, bertujuan untuk mengetahui tingkat kualitas MAN/ MAS dengan melihat berbagai aspek, diantaranya: Kurikulum, proses pembelajaran, Lulusan, pendidiak dan Tenaga Kependidikan, Sarpras, pengelolaan, Pembiayaan, Penilaian Madrasah dan Ciri Khas Madrasah, serta memetakan kualitas madrasah berdasarkan SNP. Adapun masalah penelitian, yaitu: Bagaimana Tingkat Ketercapaian Kualitas MAN/MAS di kabupaten Kolaka.

Sehingga pemetaan kualitas urgen untuk dilakukan di kabupaten Kolaka untuk memberikan informasi kepada pemerintah dalam menyusun dan menetapkan kebijakan. Maka masalah penelitian adalah Bagaimana Tingkat Ketercapaian Madrasah Aliyah di Kabupaten Kolaka? Tujuan penelitian, yaitu untuk mengetahui sejauh mana ketercapaian Madrasah Aliyah dan Pemetaan kategori. Adapunkegunaannya adalah: a) Secara Praktis; Merupakan bahan pertimbangan Kementerian Agama dalam merancang dan menetapkan kebijakan dalam peningkatan kualitas pada komponen satuan pendidikan di Kabupaten Kolaka, b) Secara Teoritis; Dapat menghasilkan konsep atau fenomena ilmu pendidikan agama

\section{Tinjauan Pustaka}

\begin{tabular}{cccr}
\multicolumn{2}{c}{ Pendidikan } & Nasional & berdasarkan \\
Pancasila dan UUD Negara & RI & 1945
\end{tabular}

mengembangkankemampuan dan membentukkarakter dan peradaban bangsa bermartabat untuk mendidik kehidupan bangsa, bertujuan untuk mengembangkan potensi peserta menjadi manusia yang percaya dan berbakti kepada Tuhan Yang MahaKuasa, berbudi luhur, cakap, kreatif, ilmu yang sehat, mandiri serta menjadi warga negara yang demokratis dan bertanggung jawab.Arti dasar dari kualitas kata dalam Kamus Bahasa Indonesia adalah "kualitet":"kualitas"; baik dan burukbarang". (Dahlan Al-Barry, 1994: 329), seperti halnya kualitas diartikan sebagai level yang bagus itu buruk sesuatu atau mutu sesuatu (Quraish Shihab, 1999: 280).

Sedangkan jika Anda memperhatikan Secara etimologis, kualitas atau kualitas ditafsirkan sebagai peningkatan tingkat menuju a perbaikan atau pendirian. Karena kualitas berarti berat atau tinggi sesuatu yang rendah.Dalamhalinikualitas Pendidikan adalah pelaksanaan Pendidikan disuatuinstitusi, sampai dimana pendidikan di institusi telah tercapai keberhasilan (A. Supriyanto, 1997: 225).

Implementasi Undang-undangNomor 20 Tahun 2003 tentang Sistem Pendidikan Nasional. diterjemahkan ke dalam PP Nomor 19 Tahun 2005 tentangStandar Nasional Pendidikan. Arahan aturan ini tentang perlunya menerapkan delapan Standar Nasional Pendidikan. Standar Isi adalah salah satu standar yang harus dikembangkan. Dokumen standar isiberdasarkanlampiran Peraturan Meneteri Pendidikan Nasional Nomor 22 Tahun 2006 tanggal 23 Mei 2006, yang mencakup : a) Kerangkan dasar dan struktur kurikulum merupakan pedoman dalam penyusunan kurikulumdi tingkat satuan pendidikan; b) Mempelajari beban bagi siswa di unit Pendidikan dasar dan menengah; c) Kurikulum pada tingkat satuan Pendidikan yang dikembangkan oleh satuan Pendidikan berdasarkan pedoman untuk menyusun kurikulum sebagai bagian integral dari Standar isi; dan d) Kalender pendidikan pada satuan pendidikan.

Istilah kurikulum awal awalnya digunakan di dunia olahraga di Yunani kuno. Curriculumberasaldari kata curirartinya pelajari, dan Curere artinya dapat ras. Dalam bahasa Inggris, kurikulum berarti rencana pelajaran (Jhon M Echols dan Hassan Sadily, 1990: 160).

Curriculum diartikan "jarak" yang harus di "tempuh" oleh pelari. Dari arti yang terkandung dalam kata itu, kurikulumnya sederhana ditafsirkan sebagai sejumlah matapelajaran yang 
harusdiambilatau diselesaikan oleh siswa untuk mendapatkan ijazah (Fuaduddin, 1997: 3).

Standar proses adalah standar pendidikan nasional yang terkait dengan pelaksanaan pembelajaran di unit Pendidikan untukmencapaikompetensilulusan, yang mengandung kriteria minimum untuk proses pembelajaran di unit Pendidikan dasar dan menengahpada jalur formal, baik sistem paket dan sistem kredit semester. PeraturanPeermendiknasNomor 41 Tahun 2007tanggal 23 November 2007 tentangstandar proses untukunit pendidikan Dasar dan Intermediate, termasuk perencanaan, pelaksanaan proses pembelajaran, evaluasi hasil belajar dan pengawasan pembelajaran yang terlaksana denganefektif dan efesien.

Pendidikan sesungguhnya merupakan sistem yang dibentuk untuk mencapai tujuan tertentu. Sistemnya adalah "sekumpulan komponen yang berinteraksi untuk mencapai tujuan tertentu". Proses sistem dimulai dari input dan kemudian prosesdengan berbagai kegiatan menggunakan teknik dan prosedur, dan sebagainyamenghasilkan output, yang akan digunakan oleh lingkungan masyarakat (Syafaruddin dan Irwan Nasution, 2005: 41-43).

Standar Kompetensi Lulusan Satuan Pendidikan berdasarkan Peraturan Permendiknas Nomor 23 Tahun 2006 tanggal 23 Mei 2006, Standar Lulusan meliputi: 1) SD/MI/SDLB/Paket A; 2) SMP/MTs/SMPLB/Paket B;3) SMA/MA/SMALB/ Paket C; 4) SMK/MAK; bertujuan meletakkan dasar kecerdasan, pengetahuan, kepribadian, akhlak mulia, dan keterampilan untuk hidup mandiri dan ikut Pendidikan lebih lanjut sesuai dengan kejuruan mereka.

Sebuah pendidikan dikatakan bermutu jika dapat mampu menghasilkan lulusan yang memenuhi empat kompetensi, yaitu: akademik, profesional, nilai dan sikap, dan kompetensi untuk menghadapi perubahan (Trianto dan Titik Triwulan Tutik, 2006: 3).

\section{Standar}

Kompetensi

Pendidik dan Kependidikan, yang diatur dalamPermendiknasNomor 16 Tahun 2007 tanggal 4 Mei 2007 tentang Kualifikasi Akademik dan Kompetensi Guru, Konselor yang diatur dalam Peraturan Permendiknas Nomor 27 Tahun 2008. Kompetensi Kepala Sekolah diatur dalam Permendiknas Nomor 13 Tahun 2007Tanggal 17 April 2007 tentang Standar Kepala Sekolah/
Madrasah, dan kompetensi pengawas diatur dalam PermendiknasNomor 12 Tahun 2007 tentang Standar Pengawas Sekolah/Madrasah.

Pengertian pendidik adalah pendidik yang menjadi tokoh, panutan, dan identifikasi bagi para peserta didik dan lingkungannya. Oleh karena itu pendidik seyogiyanya memiliki kepribadian yang mencakup tanggung jawab, kemandirian dan kedisiplinan (E. Mulyasa, 2005: 37). Menurut Undang-Undang RI Nomor 14 tahun 2005 pasal 1 (1) dimaksudkan "Guru adalah pendidik profesional dengan tugas utama mendidik, mengajar, membimbing, mengarahkan, melatih, mengevaluasi dan mengevaluasi siswa dalam pendidikan dini dalam pendidikan formal, dasar dan menengah.

Standar Sarana dan Prasarana Satuan Pendidikan dikembangkan berdasarkan SD/ MI, SMP/MTs, dan SMA/MA, berdasarkan PermendiknasNomor 24 tahun 2007 tanggal 28 Juni 2007, yang meliputi: Unit Pendidikan, Tanah, Bangunan, Infrastruktur dan Fasilitas. Pengadaan sarana dan prasarana sekolah biasanya dilakukan untuk memenuhi kebutuhan sesuai dengan perkembangan program sekolah, mengganti barang yang rusak, hilang, tersingkir atau sebab lain yang dapat dibenarkan

Untuk proses pengadaan sarana pendidikan, terdapat beberapa yang harus ditempuh, yaitu (1) pembelian dengan biaya pemerintah, (2) pembelian dengan biaya dari SPP, (3) kontribusi komunitas. (Hasbullah, 2007: 120). Peralatan atau fasilitas pendidikan adalah peralatan yang dibutuhkan yang berfungsi sebagai sarana untuk mendukung pelaksanaan tugas di sekolah.(Piet A. Sahertian, 1994: 170)

Prasana pendidikan adalah semua peralatan dasar yang secara tidak langsung mendukungpelaksanaan disekolah. Penekanan dalam arti itu sifatnya, sarananya langsung, dan infrastruktur tidak langsung mendukung proses pendidikan(Barnawi \& M. Arifin, 2012: 48).

Standar Pengelolaan Pendidikan, merujuk pada PermendiknasNomor 19 tahun 2007 tanggal 23 Mei 2007 tentang Standar Manajemen yang meliputi: Perencanaan Program, Pelaksanaan Rencana Kerja, Pengawasan dan Evaluasi, Kepemimpinan Kepala Sekolah / Madrasah, Sistem Informasi Manajemen, dan Penilaian Khusus.

Manajemen sering diartikan sebagai pengetahuan, tips dan profesi. Dikatakan ilmu karena manajemen dipandang sebagai bidang 
pengetahuan sistemikmencoba mengerti mengapa dan bagaimana manusiabekerja. Diberitahu tipskarena manajemen mencapai target melalui cara mengelola orang lainmelaksanakan tugas.

Dilihat sebagai profesi karena manajemen didasarkan pada keahlian khusus untuk mencapai profesi, manajer dan profesional dituntut oleh kode etik. (Nanang Fattah, 2009: 1) Standar Pembiayaan Unit Pendidikan diatur dalam Peraturan Menteri Pendidikan Nasional Nomor 69 tahun 2009 tentang Standar Biaya Operasional dan Non-personalia tahun 2009 untuk SD / MI / SDLB, SMP / MTs / SMPLB, SMA / MA / SMALB, dan sekolah kejuruan, yang meliputi: Ketentuan tentang jumlah kelas per sekolah / program keahlian dan jumlah siswa per kelas untuk menghitung biaya operasional nonpersonil.

Biaya pendidikan menurut sumber diklasifikasikan sebagai biaya yang dikeluarkan oleh pemerintah baik pustakawan dan daerah, biaya yang dikeluarkan oleh komunitas tua siswa / wali, dan lembaga pendidikan itu sendiri. (Harsono, 2007: 10) Biaya langsung terdiri dari biaya yang dikeluarkan untuk tujuan pelaksanaan pengajaran dan kegiatan belajar siswa, dalam bentuk pembelian alat belajar, alat belajar, biaya transportasi, gaji guru, baik yang dikeluarkan oleh pemerintah, orang tua, atau siswa (Nanang Fattah, 2004: 23)

Standar Penilaian Pendidikan, Permendiknas Nomor 20 tahun 2007 tanggal 11 Juni 2007, yang meliputi: Definisi, Prinsip, Teknik dan Instrumen, Mekanisme dan prosedur untuk penilaian, penilaian Pendidik, Penilaian Unit Pendidikan dan Pemerintah. Penilaian dilakukan setelah siswa menjawab pertanyaan yang terkandung dalam tes. Hasil jawaban siswa ditafsirkan dalam bentuk nilai (Calongesi, James S, 1995: 21) Evaluasimakna yang lebih luas dan lebih komprehensif daripada pengukuran atau penilaian.Evaluasi hasil belajar merupakan penilaian siswa dalam mengekspresikankeseluruhan proses belajar siswa (Suharsimi Ari Kunto, 2009: 3).

Penelitian ini mengungkap kondisi real standar pendidikan nasional (SNP) berdasarkan delapan aspek/komponen dan diakumulasi untuk mengetahui tingkat kualitas madrasah aliyah berdasarkan kategori. Adapun aspek yang dijaring di madrasah, sebagai berikut: 1) Kurikulum (mengembangkan perangkat pembelajaran pada kompetensi sikap, spritual, sosial, keterampilan ruang lingkup pembelajaran; mengembangkan kurikulum sesuai pedoman dan prosedur operasional serta pelaksanaan silabus dan RPP); 2) Proses (mengalokasikan waktu dan beban belajar, serta pengelolaan kelas); 3) Lulusan (mencerminkan sikap pembelajaran dan sehat jasmani/rohani; keterampilan berfikir dan bertindak; siswa per rombel, penggunaan buku teks dan pelaksanaan pengawasan); 4) Pendidik/Kependidikan (tingkat kualifikasi guru/staf dan sertifikasi); 5) Sarpras (lahan, bangunan, kelengkapan sarana dan pemeliharaan); 6) Pengelolaan (Visi dan misi, RKJM/RKT, pedoman dan sistem informasi manajemen); 7) Pembiayaan ( rencana kerja anggra, biaya operasional, sumbangan, pembukuan dan pelaporan keuangan); 8) Evaluasi (kriteria KKM, penilaian hasil belajar dan ketentuan kelulusan siswa).

\section{METODE PENELITIAN}

Jenis penelitian adalah penelitian survei yang akan mengungkap kondisi real madrasah aliyah dengan menggunakan teori edukasi yang relevan pada obyek penelitian. Sasaran penelitian adalah MAN/MAS di Kabupaten Kolaka dengan menggunakan metode kuantitatif. Adapun sumber data adalah Kementerian Agama Propinsi Sulawesi Tenggara, Kementerian Agama Kabupaten Kolaka, Komponen Madrasah Aliyah, dan BPS. Sedangkan Instrumen penelitian berupa angket, wawancara, dan observasi.

\section{PEMBAHASAN \\ Kondisi Madrasah}

Secara keseluruhan jumlah madrasah di Kabupaten Kolaka terdapat 51 lembaga pendidikan agama dari berbagai tingkatan yaitu, sebagai berikut: MI 16 lembaga (MIN 2 dan MIS 14), MTs 24 (MTsN 2 dan MTs 22), dan MA 11 (MAN 2 dan MAS 9). Jumlah guru madrasah 830 (PNS 142 dan Non-PNS 688) dan Jumlah siswa 6.870, adapun jumlah sebagai berikut: a) Guru RA 76 (PNS 4 dan Non-PNS 72), Guru MI 218 (PNS 43 dan NonPNS 175), Guru MTs 296 (PNS 44 dan Non-PNS 252), Guru MA 240 (PNS 51 dan Non-PNS 189); b) jumlah siswa RA 505, MI 2.598, MTs 2.355, dan MA 1.412.

Lembaga pendidikan Agama (madrasah) yang tersebar di Kabupaten Kolaka berjumlah 11 Madrasah Aliyah, adapun rincian pada tabel, sebagai berikut: 
Tabel 1. Jumlah MA berdasarkan Guru dan Siswa

\begin{tabular}{lllll}
\hline NO & MADRASAH & GURU & SISWA & RASIO \\
\hline 1. & MAN 1 KOLAKA & 23 & 559 & 24,3 \\
2. & MAN 2 KOLAKA & 22 & 516 & 23,4 \\
3. & MA. Al - Mawahdah Warrahmah & 24 & 145 & 6 \\
4. & MA. At-Tarbiyah Islamiyah & 15 & 49 & 3,2 \\
5. & MA. Darul Arqam Ponrewaru & 15 & 117 & 7,8 \\
6. & MA. Darul Istiqamah & 11 & 27 & 2,25 \\
7. & MA. Darul Hikmah Tosiba & 12 & 43 & 3,58 \\
8. & MA. Nurul Yaqin Dawi-Dawi & 16 & 140 & 8,75 \\
9. & MA. Baitul Arqom Polinggona & 21 & 185 & 8,80 \\
10. & MA. Nurul Hidayah Al - Mincis & 10 & 21 & 2,1 \\
11. & MA. Plus Keterampilan Al Muhajirin & 11 & 9 & 0,81 \\
\hline JUMLAH & & 180 & 1.811 & 90,99 \\
\hline
\end{tabular}

Sumber Data Kementerian Agama Kab. Kolaka

Keberadaan MA (N/S) tersebar Kecamatan di Kabupaten Kolaka, yang memiliki khas tersendiri. Dimana madrasah aliyah ada yang memiliki kelas jauh, memiliki beberapa lembaga pendidikan formal (RA, MI, MTs, dan STAI), Pondok Pesantren, dan Rumah Tahfiz. Terdapat dua lembaga pendidikan agama (MAS) yang memprogramkan pembelajaran Tahfiz (MA. Darul Istiqamah dan Nurul Yaqin Dawi-Dawi).

Secara kuantitas kondisi siswa, guru dan staf pada madrasah aliyah swasta belum signifikan, begitupun halnya dengan minat serta kepedulian masyarakat terhadap madrasah masih rendah. Para guru MAS memiliki keterbatasan dalam meningkatkan SDM. Sehingga, kegiatan pengembangan dalam meningkatkan sumber daya manusia dominan hanya sosialisasi dibanding kegiatan pendidikan dan pelatihan (diklat).

\section{Kualitas MAN/MAS}

Berdasarkan grafik diatas, secara generalisasi menunjukkan bahwa adanya variasi tingkat capaian pada aspek tersebut. Adapun yang dimaksud bervariasi, yaitu: Standar Kurikulum, Lulusan, Proses, Tenaga Pendidik dan staf, Pengelolaan, Sarpras, pembiayaan, Sarana dan Prasarana, Pengelolaan, Pembiayaan, dan Penilaian.

Secara kuantitas dan kualitas dalam pengembangan madrasah masih memerlukan dukungan dari masyarakat dan pemerintah, terutama pada aspek sarana dan prasarana, tenaga pendidik dan kependidikan, dan strategi pengelolaan (manajemen) madrasah. Komponen inilah yang menjadi urgen disetiap madrasah, sehingga belum bisa mewujudkan harapan masyarakat secara signifikan dalam PBM di lembaga pendidikan agama (MAS) khususnya.

Lebih jelasnya akan diuraikan secara rinci pada tabel, berdasarkan tingkat capaian SNP pada MAN/MAS di Kabupaten Kolaka, sebagai berikut:

\section{Kualitas Standar}

Tabel 2. Ciri Khas

\begin{tabular}{|c|c|c|c|}
\hline $\mathrm{NO}$ & $\begin{array}{l}\text { PENGEM } \\
\text { BANGAN }\end{array}$ & SKOR & $\begin{array}{l}\text { TKT } \\
\text { CAPAIAN }\end{array}$ \\
\hline 1 & $\begin{array}{l}\text { Pengembangan } \\
\text { Mata Pelajaran } \\
\text { Agama }\end{array}$ & 4,1 & $82 \%$ \\
\hline 2 & $\begin{array}{l}\text { Pengembangan } \\
\text { Ekstrakurikuler } \\
\text { Keagamaan }\end{array}$ & 48 & $18 \%$ \\
\hline 3 & $\begin{array}{l}\text { Penciptaan Sua- } \\
\text { sana Keagamaan }\end{array}$ & 98 & $89 \%$ \\
\hline 4 & $\begin{array}{l}\text { Pendalaman Aja- } \\
\text { ran Agama }\end{array}$ & 96 & $67 \%$ \\
\hline
\end{tabular}

\begin{tabular}{ll}
\hline TINGKAT KUALITAS & $55,7 \%$ \\
\hline
\end{tabular}

Indikator tingkat capaian "ciri khas" merupakan standar kualitas. Dimana, standar tersebut merupakan bahan penilaian pada lembaga pendidikan agama (madrasah).

Pada umumnya madrasah telah mengajarkan lima mata pelajaran pendidikan agama, diantaranya: Qur'an Hadits, Fiqh, Aqidah Akhlak, SKI, dan Bahasa Arab. Ini merupakan landasan wajib yang harus diajarakan, karena termaktub dalam kurikulum 13. Namun, dalam implementasi pembelajaran ekstrakurikuler, belum teraplikasi 
secara signifikan, karena adanya batasan-batasan yang dimiliki madrasah, diantaranya: fasilitas pembelajaran, waktu dan SDM pengelola (guru).

Adapun indikator ekstrakurikuler keagamaan yang dijadikan sebagai penilaian adalah: a) Peningkatan pendalaman Aqidah (pengajian jum'at sore, shalat dhuha setiap pagi, tadarrus setelah shalat dhuha, dan zikir asmaul husnah); b) Peningkatan kemakhiran dan pemahaman Alqur'an Hadits (TPQ); c) Peningkatan pengamalan ibadah (safari ramadhan); d) Peningkatan Akhlak (kultum dari guru setiap pagi dan kultum dari siswa setelah shalat dhuhur); e) Peningkatan kemampuan berbahasa Arab (latihan ceramah bahasa Arab); dan f) Peningkatan pengetahuan terhadap sejarah kebudayaan Islam.

Implementasi PBM pada kegiatan ekstrakurikuler keagamaan, dominan madrasah memfokuskan pada "peningkatan dan pendalaman aqidah akhlak". Walaupun masih terdapat dua madrasah (MAS Darul Hikmah dan MAS Plus Keterampilan Al-Muhajirin) yang belum mengembangkan kegiatan. Namun, dari akumulasi tidak mengurangi tingkat capaian pada ciri khas madrasah dengan kategori "Tinggi".

Tabel 3. Kurikulum

\begin{tabular}{llll}
\hline NO & $\begin{array}{l}\text { PENGEM } \\
\text { BANGAN }\end{array}$ & SKOR & $\begin{array}{l}\text { TKT } \\
\text { CAPAIAN }\end{array}$ \\
\hline 1 & $\begin{array}{l}\text { Pengembangan } \\
\text { Kompetensi Siswa }\end{array}$ & 19,3 & $77,1 \%$ \\
2 & $\begin{array}{l}\text { Pelibatan Pada } \\
\text { kegiatan pengem- } \\
\text { bangan kurikulum }\end{array}$ & 52 & $95 \%$ \\
3 & $\begin{array}{l}\text { Kegiatan Penyusu- } \\
\text { nan Kurikulum }\end{array}$ & 58 & $88 \%$ \\
4 & $\begin{array}{l}\text { Prosedur pengem- } \\
\text { bangan Kurikulum }\end{array}$ & 38 & $86 \%$ \\
5 & $\begin{array}{l}\text { Pelaksanaan Kuri- } \\
\text { kulum }\end{array}$ & 39 & $100 \%$ \\
6 & $\begin{array}{l}\text { Pengembangan } \\
\text { Silabus } \\
7\end{array}$ & 99 & $73 \%$ \\
Pengembangan & 3,6 & $82,9 \%$ \\
\hline
\end{tabular}

Berdasarkan indikator pengembangan kurikulum tentang implementasinya, masih memerlukan bimbingan dan pembinaan bagi guru madrasah, khususnya MAS Darul Hikmah. Sejak diberlakukannya kurikulum 13 pada lembaga pendidikan (madrasah), pemahaman pengelola bervariasi dalam mengaplikasikan perangkat tersebut.

Substansi kurikulum 13 mengemas kompetensi sosial dan religius, dalam operasionalnya memerlukan dukungan perangkat/ media pembelajaran. Sehingga, pelaksanaan dapat diaplikasikan berdasarkan ketentuan atau aturan dalam penerapan K13. Ada beberapa kendala/ dalam pengimplementasiannya yaitu: kurangnya sosialisasi; b) mengkolaborasi kurikulum (pesantren dan madrasah); c) terbatasnya SDM pengelola dan anggaran.

Regulasi penganggaran K13 hanya pada madrasah negeri (induk) saja, sehingga dibutuhkan inovasi dan kreatifitas madrasah swasta dalam memenuhi pengembangan perangkat pembelajaran berdasarkan pembelajaran pada setiap tingkat kelas. Namun, akumulasi pengembangan kurikulum madrasah terkategori "Sangat Tinggi".

Tabel 4. Kelulusan

\begin{tabular}{llll}
\hline NO & $\begin{array}{l}\text { PERILAKU DAN } \\
\text { SIKAP SISWA }\end{array}$ & SKOR & $\begin{array}{l}\text { TKT } \\
\text { CAPAIAN }\end{array}$ \\
\hline 1 & Sikap Taqwa & 104 & $95 \%$ \\
2 & Sikap Sosial & 54 & $98 \%$ \\
3 & Sikap Belajar & 34 & $44 \%$ \\
4 & Sikap Hidup Sehat & 58 & $88 \%$ \\
5 & Sikap Berfikir & 34 & $77 \%$ \\
6 & Keterampilan Ilmiah & 35 & $45 \%$ \\
7 & Keterampilan & 59 & $89 \%$ \\
& Bertindak & & \\
\hline
\end{tabular}

$76,4 \%$

Madrasah dikatakan bermutu, apabila mampu menghasilkan suatu lulusan yang bisa memenuhi empat kompetensi, diantaranya: kompetensi nilai dan sikap. Tingkat capaian madrasah pada standar kelulusan terkategori "Tinggi". Walaupun masih terdapat beberapa indikator, yang masih memerlukan peningkatan guna mencerminkan sikap pembelajaran sejati melalui gerakan literasi madrasah dan keterampilan berfikir siswa secara kreatif, produktif dan kritis.

Dari tujuh indikator sikap belajar, belum semua dapat di implementasikan pihak madrasah. Adapun gerakan literasi yang dilaksanakan, adalah: membaca buku, memajang karya tulis dan lomba 
terkait literasi. Sedangkan yang terkait dengan berfikir secara kreatif, produktif dan kritis adalah: study wisata belum dapat diimplementasikan, karena memerlukan biaya operasional yang tidak sedikit serta kegiatan seminar dan workshop.

Tabel 5. Proses Pendidikan

\begin{tabular}{llll}
\hline NO & $\begin{array}{l}\text { PENGALOKASIAN } \\
\text { WAKTU DAN } \\
\text { EVALUASI }\end{array}$ & SKOR & $\begin{array}{l}\text { TKT } \\
\text { CAPAIAN }\end{array}$ \\
\hline 1 & Waktu Belajar & 25 & $57 \%$ \\
2 & $\begin{array}{l}\text { Jumlah Rombongan } \\
\text { Belajar dan }\end{array}$ & 6,4 & $65 \%$ \\
& $\begin{array}{l}\text { Penggunaan Buku } \\
3\end{array}$ & Pengelolaan Kelas \\
4 & Proses Pembelajaran & 32,2 & $71,5 \%$ \\
5 & $\begin{array}{l}\text { Pengawasan proses } \\
\text { pembelajaran }\end{array}$ & 8,5 & $85,5 \%$ \\
6 & $\begin{array}{l}\text { Pemantauan proses } \\
\text { pembelajaran }\end{array}$ & 36 & $55 \%$ \\
7 & $\begin{array}{l}\text { Tindak lanjut hasil } \\
\text { supervisi }\end{array}$ & 26 & $59 \%$ \\
8 & $\begin{array}{l}\text { Laporan pengawasan, } \\
\text { supervisi, dan } \\
\text { pemantauan }\end{array}$ & $\mathbf{6 8} \%$ \\
9 & $\begin{array}{l}\text { Pelaksanaan hasil } \\
\text { tindak lanjut }\end{array}$ & 30 & $78 \%$ \\
\hline TINGKAT KUALITAS & & $73,3 \%$ \\
\hline
\end{tabular}

Dalam proses pendidikan, terdapat sembilan indikator yang dijadikan sebagai rujukan guna meningkatkan kualitas terutama pada pengalokasian waktu pembelajaran. Karena durasi pembelajaran dan beban belajar merupakan suatu pedoman untuk dapat mengukur tingkat pencapaian PBM dan pelaksanaan ujian semester.

Pemantauan proses pembelajaran salah satu cara untuk bisa meningkatakan output dari berbagai aspek pendidikan. Kepala madrasah memiliki wewenang dalam hal pemantauan. Adapun yang dijadikan sebagai bahan pemantauan, sebagai berikut: Diskusi kelompok terfocus, pengamatan, pencatatan, perekaman, wawancara, dan pendokumentasian. Sebahagian besar madrasah hanya mengimplementasikan pemantauan pada aspek pengamatan dan pencatatan saja. Pemantauan dilaksanakan, agar bisa mengetahui secara pasti metode dan cara mengajar serta menjadikan pedoman penilaian terhadap guru.
Sedangkan menidaklanjuti hasil laporan pengawasan, contoh, diskusi, konsultasi dan pelatihan. Hanya konsultasi dan pelatihan yang belum semua diimplementasikan kepala madarsah. Namun, secara keseluruhan menunjukkan tingkat capaian madrasah dengan melihat sembilan indikator pada proses pendidikan terkategori "Tinggi".

Tabel 6. Tenaga Pendidik dan Kependidikan

\begin{tabular}{|c|c|c|c|}
\hline $\mathrm{NO}$ & $\begin{array}{l}\text { KUALIFIKASI } \\
\text { PENDIDIK/ } \\
\text { KEPENDIDIKN } \\
\end{array}$ & SKOR & $\begin{array}{l}\text { TKT } \\
\text { CAPAIAN }\end{array}$ \\
\hline 1 & $\begin{array}{l}\text { Kualifikasi dan } \\
\text { Sertifikasi Pendidik }\end{array}$ & 6,5 & $65 \%$ \\
\hline 2 & Kompetensi Guru & 29,4 & $83 \%$ \\
\hline 3 & $\begin{array}{l}\text { Persyaratan Kepala } \\
\text { Madrasah }\end{array}$ & 63 & $64 \%$ \\
\hline 4 & $\begin{array}{l}\text { Kompetensi } \\
\text { Manajerial Kepala } \\
\text { Madarsah }\end{array}$ & 138 & $78 \%$ \\
\hline 5 & $\begin{array}{l}\text { Kompetensi } \\
\text { kewirausahaan } \\
\text { Kepala Madrasah }\end{array}$ & 36 & $65 \%$ \\
\hline 6 & $\begin{array}{l}\text { Kompetensi } \\
\text { Supervisi Kepala } \\
\text { Madrasah }\end{array}$ & 28 & $64 \%$ \\
\hline 7 & $\begin{array}{l}\text { Tenaga } \\
\text { Kependidikan }\end{array}$ & 9,8 & $39 \%$ \\
\hline 8 & Tenaga Khusus & 17 & $31 \%$ \\
\hline \multicolumn{3}{|c|}{ TINGKAT KUALITAS } & $65,2 \%$ \\
\hline
\end{tabular}

Tenaga stafmerupkan penunjang penyelenggaraan pendidikan (Suharno, 2008: 14)

Sedangkan Tenaga kependidikan non-guru di angkat untuk menunjang penyelenggaraan pendidikan non-formal dan informal.

Kualifikasi tenaga pendidik rata-rata sarjana dan memiliki sertifikan pendidik dan kompetensi. Begitupun halnya dengan para kepala madrasah memiliki kompetensi manajerial. Walaupun masih terdapat beberapa madrasah yang yang masih mengampuh mata pelajaran sampai 4 bidang study dan sarjana umum.

Sedangkan tenaga administrasi (kependidikan) madrasah memiliki latar belakang sarjana yang telah mengabdi 4 tahun dan Diploma berpengalaman $5-8$ tahun. Secara kuantitas tenaga adminsitrasi sangat minim, sehingga sistem yang diterapkan dengan cara kolaborasi (saling 
membantu) sesama guru. Bahkan terdapat beberapa madrasah, kegiatan administrasinya ditangani langsung oleh pihak yayasan.

Petugas khusus madrasah, dintaranya: penjaga sekolah, pesuruh, dan pengemudi. Secara keseluruhan belum dapat terpenuhi, karena adanya batasan yang dimiliki seperti: anggaran dan kondisi lingkungan. Sehingga, pihak madrasah/yayasan hanya memiliki petugas yang akan melaksanakan layanan khusus secara rangkap (penjaga dan tenaga kebersihan) saja.

Adapun tingkat capaian madrasah pada kompetensi guru dan staf terkateori "Tinggi". Ini disebabkan oleh strategi dan kebijakan yang diterapkan oleh kepala madrasah dan yayasan dalam mengimplementasikan PBM dan mengelola kegiatan administrasi.

Tabel 7. Sarana dan Prasarana

\begin{tabular}{llll}
\hline NO & KEPEMILIKAN LAHAN/BANGUNAN & SKOR & TKT CAPAIAN \\
\hline 1 & Lahan Madrasah & 42 & $74 \%$ \\
2 & Bangunan Madrasah & 36 & $67 \%$ \\
3 & Persyaratan Keselamatan \& Kesehatan Madrasah & 50 & $91 \%$ \\
4 & Listrik dan Pemeliharaan Madrasah & 7,8 & $78 \%$ \\
5 & Kelengkapan Prasarana Madrasah & 113 & $57 \%$ \\
6 & Ruang Kelas dan Perpustakaan & 5,6 & $56 \%$ \\
7 & Ruang Laboratorium (Kimia, Fizika, Biologi, Bahasa) & 52 & $19,5 \%$ \\
8 & Ruang Komputer & 30 & $68 \%$ \\
9 & Ruang Pimpinan & 68 & $77 \%$ \\
10 & Ruang Guru & 67 & $68 \%$ \\
11 & Ruang Tenaga Administrasi & 69 & $52 \%$ \\
12 & Tempat Beribadah & 25 & $57 \%$ \\
13 & Ruang Konseling (BK) & 30 & $30 \%$ \\
14 & Ruang Usaha Kesehatan Sekolah (UKS) & 70 & $42 \%$ \\
15 & Ruang OSIS & 15 & $27 \%$ \\
16 & Jamban & 40 & $73 \%$ \\
17 & Gudang & 16 & $36 \%$ \\
18 & T4 bermain, Olah raga, kesenian, upacara, Ketrampi & 24 & $44 \%$ \\
19 & Ruang Sirkulasi & 19 & $35 \%$ \\
20 & Kantin & 33 & $60 \%$ \\
21 & Tempat parkir & 21 & $38 \%$ \\
\hline TINGKAT KUALITAS & & $52,5 \%$ \\
\hline
\end{tabular}

Berdasarkan dari beberapa hasil penelitian Litbang Agama tentang "Kualitas Madrasah", terutama pada aspek sarana dan prasarana. Sehingga pihak madrasah dalam mengimplementasikan proses belajar mengajar mengkondisikan fasilitas/ media sesuai kebutuhan. Pada umumnya pihak lembaga pendidikan lebih menguitamakan pengadaan ruang pembelajaran dibanding ruang laboratorium, perpustakaan, apalagi ruang Osis dan lahan parkir.

Kepemilikan bangunan madrasah memenuhi persyaratan kesehatan dan keselamatan, walaupun sebahagian belum memiliki ruang laboratorium. Namun dalam hal pemeliharaan/perawatan tetap terjaga, seperi yang dilakukan oleh MAN 1 Kolaka. Dimana melakukan perawatan berkala kurang dari 5 tahun, karena menyesuaikan anggaran pemeliharaan pada DIPA pertahun.

Pengadaan fasilitas PBM tidak terlepas dari bantuan pemerintah, yaitu: Dana BOS, tetapi pengadaan fasilitas pada kegiatan ekstrakurikuler dominan pihak madrasah berupaya secara mandiri, salah satu contoh: MAN I Kolaka dan MAS Nurul Yaqin dawi-dawi pemenuhan fasilitas pada kegiatan pengembangan diri siswa, lebih mengutamakan usaha sendiri. Strategi yang ditempuh adalah sering mengikuti/menampilkan ikon madrasah baik tingkat lokal sampai nasional, ini merupakan 
sosialisasi dan promosi. Pada prinsipnya "bagaimana bisa dikenal kalau tidak pernah memperlihatkan hasil". Hal ini merupakan modal dalam memajukan atau mengembangkan madrasah kedepan.

Dalam tingkat capaian kompetensi sarana dan prasarana madrasah secara keseluruhan terkategori "Rendah". Walaupun dalam hal bangunan telah memenuhi persyaratan keselamatan dan kesehatan, tetapi fasilitas masih sangat minim dalam mengembangkan PBM.

Tabel 8. Pengelolaan

\begin{tabular}{|c|c|c|c|}
\hline $\mathrm{NO}$ & $\begin{array}{l}\text { LANDASAN / } \\
\text { PEDOMAN }\end{array}$ & SKOR & $\begin{array}{l}\text { TKT } \\
\text { CAPAIAN }\end{array}$ \\
\hline 1 & $\begin{array}{l}\text { Visi dan Misi } \\
\text { Madrasah }\end{array}$ & 38 & $86 \%$ \\
\hline 2 & $\begin{array}{l}\text { Perumusunan RKJM } \\
\text { dan RKT }\end{array}$ & 30 & $68 \%$ \\
\hline 3 & Pedoman Pengelolaan & 96 & $97 \%$ \\
\hline 4 & $\begin{array}{l}\text { Struktur Organisasi } \\
\text { Madrasah }\end{array}$ & 134 & $91,5 \%$ \\
\hline 5 & $\begin{array}{l}\text { Pelaksanaan Rencana } \\
\text { Kerja Tahunan }\end{array}$ & 3,8 & $76 \%$ \\
\hline 6 & $\begin{array}{l}\text { Pelaksanaan Proses } \\
\text { Peminatan }\end{array}$ & 23 & $53 \%$ \\
\hline 7 & $\begin{array}{l}\text { Pengelolaan Kegiatan } \\
\text { Bidang Kurikulum }\end{array}$ & 51 & $93 \%$ \\
\hline 8 & $\begin{array}{l}\text { Pendayagunaan Guru } \\
\text { dan Staf }\end{array}$ & 33 & $75 \%$ \\
\hline 9 & $\begin{array}{l}\text { Penilaian Kinerja } \\
\text { Tenaga Pendidik dan } \\
\text { Kependidikan }\end{array}$ & 40 & $73 \%$ \\
\hline 10 & $\begin{array}{l}\text { Pedoman pengelolaan } \\
\text { pembiayaan Inves dan } \\
\text { Oprasi }\end{array}$ & 37 & $67 \%$ \\
\hline 11 & Pelibatan Masyarakat & 41 & $62 \%$ \\
\hline 12 & Evaluasi Diri & 3,7 & $75 \%$ \\
\hline 13 & $\begin{array}{l}\text { Pelaksanaan Tugas } \\
\text { Kepemimpinan }\end{array}$ & 72 & $73 \%$ \\
\hline 14 & $\begin{array}{l}\text { Penerapam prinsip2 } \\
\text { Kepemimpinan } \\
\text { Pembelajaran }\end{array}$ & 42 & $64 \%$ \\
\hline 15 & $\begin{array}{l}\text { Kepemilikan Sistem } \\
\text { Informasi Manajemen } \\
(\text { SIM) }\end{array}$ & 10 & $23 \%$ \\
\hline \multicolumn{3}{|c|}{ TINGKAT KUALITAS } & $72,7 \%$ \\
\hline
\end{tabular}

Pedoman pengelolaan yang di miliki madrasah sangat bervariatif, baik pengembangan kurikulum, pembagian tugas guru dan tenaga kependidikan, peraturan akademik, maupun biaya operasional.
Strategi dan kebijakan merupakan hal terpenting yang harus dimiliki pihak pengelola terutama para kepala madrasah, dalam mengembangkan suatu lembaga pendidikan (madrasah).

Sedangkan pengarturan pembukuan serta mengatur tentang kewenangan dan tanggung jawab madrasah dalam membelanjakan anggaran, sepenuhnya adalah wewenang yayasan.

Madrasah telah melibatkan lembaga pendidikan, keagamaan dan kemasyarakatan, dunia usaha, dan pengembangan minat dan bakat. Sedangkan pelaksanaannya sekali dalam 1-3 tahun.

Kepala madrasah mengelola madrasah, yang meliputi: membangun tujuan bersama, dalam pengembangan kurikulum, mengembangan motivasi guru, , mengembangkan sistem penilaian, dan mengambil keputusan berbasis data. Sehingga yang dominan di aplikasikan pihak madrasah adalah aspek Mengembangkan motivasi guru, mengembangkan sistem penilaian, dan mengembangakan tujuan bersama.

Secara keseluruhan menunjukkan tingkat capaian madrasah terhadap komponen pengelolaan pendidikan terkategori "Tinggi".

Tabel 9. Pembiayaan

\begin{tabular}{|c|c|c|c|}
\hline $\mathrm{NO}$ & $\begin{array}{l}\text { ALOKASI } \\
\text { ANGGARAN }\end{array}$ & SKOR & $\begin{array}{l}\text { TKT } \\
\text { CAPAIAN }\end{array}$ \\
\hline 1 & RKA & 33 & $75 \%$ \\
\hline 2 & $\begin{array}{l}\text { Biaya Operasional } \\
\text { Non-Personalia }\end{array}$ & 86 & $77 \%$ \\
\hline 3 & Dokumen Sarpras & 3,4 & $67 \%$ \\
\hline 4 & $\begin{array}{l}\text { Biaya Operasional } \\
\text { Tenaga Pendidik dan } \\
\text { Kependidikan }\end{array}$ & 35 & $80 \%$ \\
\hline 5 & Realisasi Pembiayaan & 3,9 & $78 \%$ \\
\hline 6 & $\begin{array}{l}\text { Pengelolaan } \\
\text { Sumbangan/dana } \\
\text { pendidikan }\end{array}$ & 29 & $66 \%$ \\
\hline 7 & Pembukuan Keuangan & 36 & $82 \%$ \\
\hline 8 & $\begin{array}{l}\text { Laporan pertanggung } \\
\text { jawaban Keuangan }\end{array}$ & 3,9 & $78 \%$ \\
\hline \multicolumn{3}{|c|}{ TINGKAT KUALITAS } & $77,8 \%$ \\
\hline
\end{tabular}

Rencana kerja anggaran (RKA) madrasah, biaya operasi nonpersonalia, dokumen sarana dan prasarana, biaya operasional guru dan tenaga kependidikan, pemanfaatan anggran, dan memiliki pembukuan dan laporan keuangan.

RKA pada alokasi anggaran untuk investasi, diperuntukkan bagi tenaga pendidikan dan 
kependidikan. Dimana terdapat lima sekolah yang belum mengalokasikan anggaran untuk investasi modal usaha. Sedangkan untuk biaya operasi nonpersonalia, hanya tiga madrasah yang mengalokasikan untuk asuransi dan dua madrasah yang belum ada alat kontrol prasarana. Begitupun halnya pada biaya operasional guru dan staf hanya diperuntukkan pada gaji, honorer kegiatan, dan intensif, kalau untuk tunjangan lain hanya lima madrasah yang telah mengalokasikan.

Rata-rata madarsah merealisasikan anggaran $91 \%$ - $100 \%$, dalam bentuk pembiayaan pengembangan pendidik dan kependidikan, ATK, pemeliharaan, perjalanan dinas, pembinaan siswa. Sedangkan pemanfaatan sumbangan pendidikan dari masyarakat dikelola secara transparan, sistimatis, efesien dan akuntabel, dengan memiliki pembukuan (buku bantukas, buku kas umum, buku bantu bank, dan tidak semua madrasah memiliki buku bantu pajak. Pelaporan/pertanggung jawaban keuangan madrasah dominan melaporkan kepada pemberi sumbangan/bantuan, yaitu: Pemerintah dan orang tua selama 3 tahun terakhir.

Pemahaman madrasah terhadap pengalokasian anggaran telah diaplikasikan secara profesional berdasarkan juknis, sehingga tingkat capaian komponen pembiayaan terkategori "Sangat Tinggi".

Tabel 10. Penilaian

\begin{tabular}{|c|c|c|c|}
\hline $\mathrm{NO}$ & $\begin{array}{l}\text { PEDOMAN } \\
\text { PENILAIAN }\end{array}$ & SKOR & $\begin{array}{l}\text { TKT } \\
\text { CAPAIAN }\end{array}$ \\
\hline 1 & KKM & 3 & $69 \%$ \\
\hline 2 & $\begin{array}{l}\text { Pelaksanaan } \\
\text { Penilaian }\end{array}$ & 37 & $73 \%$ \\
\hline 3 & $\begin{array}{l}\text { Pelaksanaan } \\
\text { Penilaian Hasil } \\
\text { Belajar }\end{array}$ & 36 & $82 \%$ \\
\hline 4 & $\begin{array}{l}\text { Pertimbangan } \\
\text { Penentuan } \\
\text { Kelulusan }\end{array}$ & 41 & $93 \%$ \\
\hline \multicolumn{2}{|c|}{ TINGKAT KUALITAS } & & $74,9 \%$ \\
\hline
\end{tabular}

Penentuan ketuntasan pada seluruh mata pelajaran telah mempertimbangkan beberapa karakteristik, yaitu: Peserta didik, mata pelajaran, kondisi satuan pendidikan, dan analisis hasil penilaian. Dimana tujuan KKM adalah untuk memperoleh hasil akhir yang valid dan akurat serta merupakan ketentuan dari kurikulum. Sehingga harus diterapkan atau dilaksanakan madarsah.

Kriteria Ketuntasan Minimal (KKM) telah diimplemetasikan 91\%-100\% berdasarkan ketentuan. Adapun cara penilaian, yaitu: sahih, objektif, adil, terbuka, holistik, dan akuntabel. Sedangkan bentuk penilaiannya berdasarkan ulangan, observasi, pemberian tugas, dan bentuk lain. Adapun jenis penilaian, yaitu: Kompetensi sikap, pengetahuan, keterampilan yang sesuai dengan karakteristik Kompetensi Dasar (KD). Begitupun dengan kriteria penilaian hasil belajar diaplikasikan dalam bentuk penilaian harian, akhir semester, akhir tahun, dan ujian madrasah.

Terkait dengan tingkat capaian madrasah terhadap komponen penilaian, terdapat dua madrasah yang masih memerlukan bimbingan dan pembinaan dalam mengimplemntasikan penilaian berdasarkan penuntasan minimal. Namun, secara keseluruhan tingkat capaian madrasah pada komponen penilaian pendidikan terkategori "Tinggi".

Berdasarkan uraian diatas, tentang kondisi tingkat capaian dengan melihat beberapa indikator pada standar/kompetensi sangar bervariatif, khususnya pada MAS dalam mengembangkan madrasah. Pengelola madrasah swasta masih memerlukan pembinaan dan bimbingan secara berkesinambungan, agar dapat meningkatkan kualitas dari berbagai aspek. Sehingga, madrasah mampu memberikan kontribusi pelayanan dan kenyamanan dalam kegiatan PBM, serta dapat bersaing dengan lembaga pendidikan lainnya.

Rekapitulasi tingkat ketercapaian pendidikan nasional madrasah berdasarkan standar/kompetensi yang telah diaplikasikan MAN/MAS Kabupaten Kolaka, sebagai berikut: 
Tabel 11. Rekapitulasi Kualitas Madrasah

\begin{tabular}{|c|c|c|c|}
\hline $\mathrm{NO}$ & $\begin{array}{l}\text { KUALITAS } \\
\text { MADRASAH }\end{array}$ & $\begin{array}{l}\text { TK. } \\
\text { CAPAIAN }\end{array}$ & KAT \\
\hline$\overline{1}$ & Ciri khas madrasah & $55,7 \%$ & $\mathrm{~T}$ \\
\hline 2 & Kualitas kurikulum & $82,9 \%$ & ST \\
\hline 3 & Kualitas kelulusan & $76,4 \%$ & ST \\
\hline 4 & $\begin{array}{l}\text { Kualitas proses } \\
\text { pendidikan }\end{array}$ & $73,3 \%$ & $\mathrm{~T}$ \\
\hline 5 & $\begin{array}{l}\text { Kualitas guru dan } \\
\text { staf }\end{array}$ & $65,2 \%$ & $\mathrm{~T}$ \\
\hline 6 & $\begin{array}{l}\text { Kualitas sarana dan } \\
\text { prasarana }\end{array}$ & $52,5 \%$ & $\mathrm{~T}$ \\
\hline 7 & Kualitas pengelolaan & $72,7 \%$ & $\mathrm{~T}$ \\
\hline 8 & Kualitas pembiayaan & $77,8 \%$ & ST \\
\hline 9 & Kualitas penilaian & $74,9 \%$ & $\mathrm{~T}$ \\
\hline$\overline{\mathrm{TI}}$ & GKAT KUALITAS & $70,2 \%$ & TINC \\
\hline
\end{tabular}

Keterangan:

1. Sangat Tinggi (ST) : $76 \%-100 \%$

2. Tinggi (T) : $51 \%-75 \%$

3. Rendah (R) : $: 26 \%-50 \%$

4. Sangat Rendah (SR) : $0 \%-25 \%$

Ketercapaian pendidikan MAN/MAS di Kabupaten Kolaka dengan melihat berbagai indikator pada komponen, masih terdapat beberapa yang perlu dikembangkan atau ditingkatkan. Diantaranya: pada aspek ciri khas, guru dan staf serta sarana dan prasarana. Walaupun ketercapaian secara keseluruhan menunjukkan "Tinggi". Tetapi pembimbingan dan pembinaan masih sangat diperlukan pihak madrasah, agar bisa mengaplikasikan PBM secara efektif dan efesien.

Salah satu indikator ciri khas yang perlu dikembangkan yaitu: pemberian tambahan materi agama yang relevan pada mata pelajaran umum (belum semua pengelola (guru) mata pelajaran umum dapat mengaplikasikan secara rutin mata pelajaran dikaitkan dengan nilai-nilai spritual keagamaan dalam pembelajaran).

Adapun keterbatasan yang dimiliki madrasah, yaitu: karena guru dominan Sarjana Umum dan masih mengampuh beberapa mata pelajaran. Sehingga penambahan materi pelajaran agama merupakan inisiatif pengelola (guru) masingmasing.

Begitupun pada peningkatan pada kegiatan ekstrakurikuler, terutama pada aspek peningkatan dan pendalaman aqidah akhlak, kemakhiran dan pemahaman terhadap alqur'an dan hadits, pengamalan ibadah, pengetahuan SKI dan kemampuan berbahasa arab. Karena program ini memerlukan dukungan yang kuat, terutama fasilitas kegiatan dan tenaga pengelola (guru).

\section{PENUTUP}

Berdasarkan hasil temuan yang telah diurai di atas, dengan melihat beberapa indikator pada komponen pendidikan masih terdapat beberapa standar yang memerlukan pembenahan dalam meningkatkan kualitas madrasah.

Ada beberapa aspek, di antaranya: dukungan fasilitas dan media pembelajaran pada kegiatan ekstrakurikuler belum efektif, Minimnya keterlibatan guru/pengelola madrasah swasta mengikuti kegiatan pengembangan diri (diklat), Manajemen madrasah masih dominan dikelola oleh yayasan, serta kurangnya penguatan/sosialisasi madrasah terhadap orang tua dalam pengembangan madrasah. dan Yang tak kalah pentingnya adalah perekrutan dan penempatan tenaga pendidik dan kependidikan belum berjalan secara selektif.

Madrasah belum memiliki konsep kemandirian yang bisa dijadikan sebagai pedoman/ rujukan dalam meningkatkan dan mengembangkan madrasah. Sementara, masih terfokus pada proses belajar mengajar dan pemenuhan ketuntasan kriteria minimal yang berdasar pada kurikulum dan silabus.

\section{UCAPAN TERIMA KASIH}

Penulis ucapkan terima kasih kepada Balai Litbang Agama Makassar, informan di Kabupaten Kolaka dan teman-teman peneliti bidang pendidikan Agama, yang telah mendukung dalam merampungkan penelitian ini. dan Tak lupa pula penulis mengucapkan terima kasih kepada redaksi Jurnal Al-Qalam dan mitra Bestari yang telah memberikan kesempatan, sehingga tulisan saya dapat dipublikasikan.

\section{DAFTARA PUSTAKA}

Barnawi \& M. Arifin. 2012. Manajemen Sarana Dan Prasarana Sekolah. Yogyakarta, Ar- Ruzz Media

Calongesi, James S. 1995. Merancang Tes Untuk Menilai Prestasi Siswa. Bandung, Institut Teknologi Bandung (ITB).

E. Mulyasa. 2005. Menjadi Guru Professional. Bandung. Remaja Rosdakarya.

Hasbullah. 2007. Otonomi Pendidikan. Jakarta, Raja Grafindo Persada

Harsono. 2007. Pengelolaan Pembiayaan Pendidikan. Yogyakarta, Pustaka Book Publisher. 
M. Dachlan Al Barry. 1994. Kamus Modern Bahasa Indonesia, Arloka. Yogyakarta.

Nanang Fatah. 2009. Landasan Manajemen Pendidikan. Bandung, Remaja Rosdakarya.

Peraturan Menteri Pendidikan Nasional Nomor 22 Tahun 2006 Tanggal 23 Mei 2006, tentang Standar Isi

Peraturan Menteri Pendidikan Nasional Nomor 41 Tahun 2007 Tanggal 23 November 2007, tentang Standar Proses

Peraturan Menteri Pendidikan Nasional Nomor 23 Tahun 2006 Tanggal 23 Mei 2006, tentang Standar Kompetensi Lulusan

Peraturan Menteri Pendidikan Nasional Nomor 16 Tahun 2007 tentang Standar Kualifikasi Akademik dan Kompetensi Guru.

Peraturan Menteri Pendidikan Nasional Nomor 24 Tahun 2007 Tanggal 28 Juni 2007, tentang Standar Sarana Dan Prasarana

Peraturan Menteri Pendidikan Nasional Nomor 19 Tahun 2007 Tanggal 23 Mei 2007, tentang Standar Pengelolaan Pendidikan

Peraturan Menteri Pendidikan Nasional Nomor 69 Tahun 2009 tentang Standar Biaya Operasional Nonpersonalia
Peraturan Menteri Pendidikan Nasional Nomor 20 Tahun 2007 Tanggal 11 Juni 2007, tentang Standar Penilaian Pendidikan

Piet A. Sihertian. 1994. Dimensi Administrasi Pendidikan. Surabaya, Usaha Nasional

Quraish Shihab. 1999. Membumikan Al-Qur'an. Mizan, Bandung

Suharsimi Ari Kunto. 2009, Dasar-dasar Evaluasi Pendidikan. Jakarta, Bumi Aksara.

Suharno 2008, Manajemen Pendidikan (Pengantar Bagi Para Calon Guru), $\quad$ Cet. II (Surakarta LPP UNS Press).

Supriyanto, A. 1997. Jurnal Ilmu Pendidikan Mutu Pendidikan Sekolah Dasar di Daerah Diseminasi, Jilid 4, IKIP.

Syafaruddin \& Irwan Nasution. 2005. Manajemen Pembelajaran. Jakarta. Quantum Teaching.

Trianto \& Titik Triwulan. 2006. Tinjauan Yuridis Hak Serta Kewajiban Pendidik (menurut UU Guru dan Dosen), Jakarta. Prestasi Pustaka.

Undang-Undang Republik Indonesia Nomor 14 Tahun 2005 pasal 1 (1), tentang Guru Dan Dosen. Bandung 2006. Citra Umbara.

Undang-Undang No. 20 tahun 2003 Tentang Sistem Pendidikan Nasional, Pasal 1, ayat (5). 